\title{
A human protein required for the second step of pre-mRNA splicing is functionally related to a yeast splicing factor
}

\author{
David S. Horowitz and Adrian R. Krainer ${ }^{1}$ \\ Cold Spring Harbor Laboratory, Cold Spring Harbor, New York 11724 USA
}

We have identified a human splicing factor required for the second step of pre-mRNA splicing. This new protein, hPrp18, is $30 \%$ identical to the yeast splicing factor Prp18. In HeLa cell extracts immunodepleted of hPrp18, the second step of pre-mRNA splicing is abolished. Splicing activity is restored by the addition of recombinant hPrp18, demonstrating that hPrp18 is required for the second step. The hPrp18 protein is bound tightly to the spliceosome only during the second step of splicing. hPrp18 is required for the splicing of several pre-mRNAs, making it the first general second-step splicing factor found in humans. Splicing activity can be restored to hPrp18-depleted HeLa cell extracts by yeast Prp18, showing that important functional regions of the proteins have been conserved. A 90-amino-acid region near the carboxyl terminus of hPrp18 is strongly homologous to yeast Prp18 and is also conserved in rice and nematodes. The homology identifies one region important for the function of both proteins and may define a new protein motif. In contrast to yeast Prp18, hPrp18 is not stably associated with any of the snRNPs. A $55-\mathrm{kD}$ protein that cross-reacts with antibodies against hPrp18 is a constituent of the U4/U6 and U4/U6 - U5 snRNP particles.

[Key Words: Pre-mRNA splicing; splicing factor; Prp18; U4/U6 snRNP]

Received September 2, 1996; revised version accepted November 25, 1996.

The splicing of pre-mRNA takes place in two sequential transesterification reactions (for review, see Umen and Guthrie 1995c; Adams et al. 1996; Krämer 1996). In the first step, the $2^{\prime}$ hydroxyl group of an adenosine within the intron attacks the phosphate at the $5^{\prime}$ splice site, forming the lariat intron-exon 2 and exon 1 intermediates. mRNA and lariat intron are produced in the second step by attack of the $3^{\prime}$ hydroxyl group of exon 1 on the phosphate at the $3^{\prime}$ splice site. The second reaction occurs within an assembled spliceosome that contains the U2, U5, and U6 small nuclear ribonucleoproteins (snRNPs) and a large number of proteins.

Several proteins required specifically for the second step-Prp16, Prp17, Prp18, and Slu7-have been studied in yeast, but in humans much less is known about the proteins involved in the second step (Umen and Guthrie 1995c). PRP18 was discovered in a screen for yeast mutants that were temperature-sensitive for pre-mRNA splicing (Vijayraghavan et al. 1989). The Prp18 protein is involved only in the second step of pre-mRNA splicing and is associated with the U5 snRNP/Vijayraghavan and Abelson 1990; Horowitz and Abelson 1993a,b). Prp18 is not essential for yeast viability, although the second step of splicing is extemely slow without it. The sequence of

${ }^{1}$ Corresponding author.

E-MAIL krainer@cshl.org; FAX (516) 367-8453.
Prp18 is not instructive, and the precise function of Prp18 in the splicing reaction is not known. The Prp16 protein, initially found as a suppressor of a branch site mutation (Couto et al. 1987), is an RNA-dependent ATPase that catalyzes a conformational change in the spliceosome before the second splicing reaction (Schwer and Guthrie 1991, 1992). Prp17 is not an essential protein, and its function in splicing remains unknown (Jones et al. 1995). Slu7, which was isolated based on its genetic interaction with the U5 snRNA (Frank et al. 1992), is involved in the recognition of $3^{\prime}$ splice sites (Frank and Guthrie 1992). Finally, the Prp8 protein, initially shown to be a first-step splicing factor (Lustig et al. 1986), is also required for the second step and appears to be involved in $3^{\prime}$ splice-site recognition (Teigelkamp et al. 1995; Umen and Guthrie 1995a,b).

Genetic studies suggest that there is a network of interactions among these second-step proteins (Frank et al. 1992; Jones et al. 1995; Umen and Guthrie 1995b). Biochemical experiments have distinguished two stages within the second step. The first stage requires the Prp16 and Prp 17 proteins, as well as the hydrolysis of ATP; the second stage, during which the transesterification reaction occurs, requires Prpl 8 and Slu 7 and is independent of ATP (Schwer and Guthrie 1991; Horowitz and Abelson 1993a; Ansari and Schwer 1995; Jones et al. 1995).

In contrast to the progress in understanding the second 
step of splicing in yeast, little is known about the second-step proteins in human splicing. Two proteins, PSF and the U5-200-kD protein, appear to be involved in the second step of splicing (Gozani et al. 1994; Lauber et al. 1996), but their precise functions are unknown. Fractions containing other activities needed for the second step have been described, but none has been purified sufficiently to allow identification of individual proteins (Krainer and Maniatis 1985; Perkins et al. 1986; Lindsey et al. 1995). The paucity of second-step factors known in humans led us to search for the homolog of Prpl8.

Of the five splicing snRNPs, only three, the U2, U5, and U6 snRNPs, appear to be required for the second step (for review, see Ares and Weiser 1995; Umen and Guthrie $1995 \mathrm{c}$ ). The U2 and U6 snRNAs base-pair to each other and to the branch site and $5^{\prime}$ splice site, forming structures necessary for both steps of splicing. A number of mutations in U2 or U6 specifically block the second step (Fabrizio and Abelson 1990; Madhani and Guthrie 1992; McPheeters and Abelson 1992; Wolff et al. 1994). The U5 snRNA base-pairs to exonic sequences at both splice sites (Newman and Norman 1992), possibly aligning the exons for splicing.

Here we report the discovery of a new human protein required for the second step of splicing. The new protein is the homolog of the yeast splicing factor Prp18. The yeast protein can substitute for the human one in the splicing reaction, showing that the mechanism of the pre-mRNA splicing reaction has been highly conserved in evolution. The sequence homology between the yeast and human proteins may define a new protein motif.

\section{Results \\ Cloning of hPrp18 by degenerate PCR}

The similarity of the yeast $\operatorname{Prp} 18$ protein sequence to the translations of two short expressed sequence tag (EST) sequences from rice ( 133 amino acids) and nematode ( 83 amino acids) suggested that they represent true homologs of Prp18. An alignment of the three sequences was used to design degenerate primers for PCR of human cDNA (Fig. 1). One of the resulting PCR fragments appeared from its sequence to be the desired one and was used to retrieve a full-length cDNA clone from a human cDNA library. The cDNA encodes a new protein, named hPrp18, which is $31 \%$ identical and $57 \%$ similar to yeast Prp18 (Fig. 1A). hPrp18 is 342 amino acids in length, 91 amino acids longer than yeast Prp18. Homology between the two proteins is strong in the carboxy-terminal third of the proteins (shown boxed in Fig. 1A) but weak elsewhere, where several gaps were introduced to give the displayed alignment. hPrp18 is more similar to the rice and nematode EST sequence fragments than it is to yeast Prp18, and a clear alignment of the four sequences can be made in the carboxy-terminal portion of hPrp18 (Fig. 1B). hPrp18 is not significantly homologous to any protein sequences in the data bases other than the three described here, and it has no known motifs.

\section{The role of hPrp18 in pre-mRNA splicing}

To study the function of hPrp18, the protein (with an amino-terminal histidine tag) was produced in Esche-
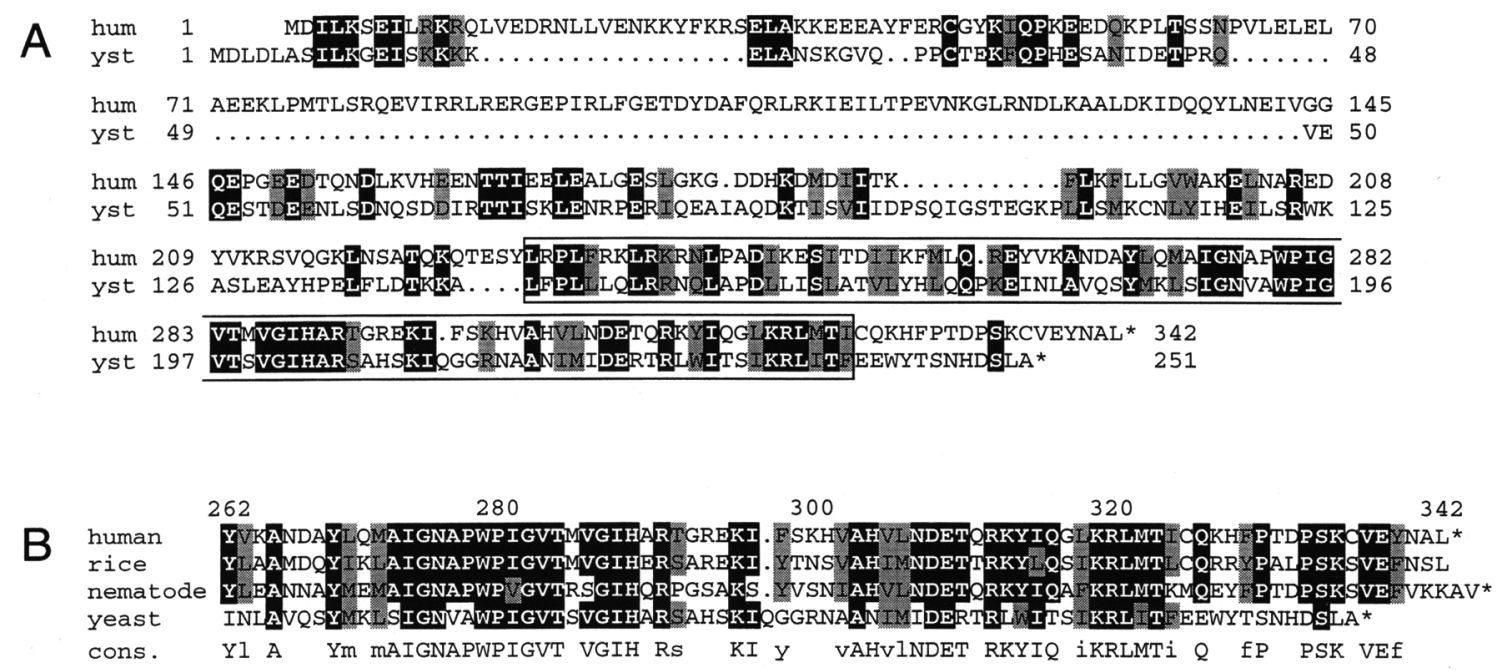

Figure 1. (A) Sequence homology of hPrp18 and yeast Prp18 proteins. An alignment of the hPrp 18 (hum) and yeast Prp18 (yst/proteins is shown. The region of highest homology is boxed; positions of identity are shown white on black, positions of similarity, black on gray. Similarities used are $D \sim E, R \sim K, T \sim S, V \sim I \sim L \sim M \sim F, W \sim Y \sim F$, and $N \sim Q$. Termination is indicated by an asterisk. The 1450-bp DNA sequence of the hPrpl 8 gene has been deposited in GenBank under accession number U51990. $(B)$ Phylogenetic conservation of the carboxy-terminal region of Prp18. The alignment of hPrp18, yeast Prp18, and fragments of possible Prp18 sequences from rice (D15798) and nematode (T01256) using the same conventions as in $A$ with the hPrpl numbering. Numbers at top are centered above the corresponding amino acid. A position is only shaded if at least three of the sequences are similar. The consensus sequence was derived from the lineup; positions of perfect or strong conservation are capitalized. At positions 272, 306, 307, and 324, where no amino acid is predominant, the amino acid from hPrp18 was arbitrarily chosen for the consensus. 
richia coli and purified to near homogeneity. Polyclonal antibodies were raised against hPrpl 8 and were used to deplete HeLa cell nuclear extracts of hPrp18. A Western blot of control and immunodepleted extracts, probed with anti-hPrp18, is shown in Figure 2A. Removal of hPrpl 8 appears to be complete, because no residual hPrp 18 could be detected on long exposure of this blot. A cross-reacting protein with an apparent molecular mass of $55 \mathrm{kD}$ was detected readily by anti-hPrp18; however, it was not significantly depleted by the antibody.

Splicing of $\beta$-globin pre-mRNA was assayed in normal and in anti-hPrp18 depleted extracts (Fig. 2B). In hPrp18depleted extract, the second step of splicing was blocked almost completely (Fig. 2B, lanes 9-12). In untreated or pre-immune-depleted extracts (Fig. 2B, lanes 1-4, 5-8), splicing intermediates (exon1 and lariat intron-exon2) were present at low levels during the reaction while the product mRNA accumulated. In anti-hPrp18 depleted extract, the splicing intermediates accumulated during the reaction, and only a trace of mRNA was produced. Quantitation of the gel shown in Figure 2 with a PhosphorImager showed that only the second step was affected by the depletion of hPrp18. The amounts of premRNA remaining at each time point in the pre-immunedepleted and anti-hPrpl8-depleted extracts are the same (to within $20 \%$ ), as are the amounts of RNA processed through the first step (the sum of the molar amounts of intermediates and products).

Purified recombinant hPrp18 could restore full splicing activity to an anti-hPrp18-depleted extract (Fig. 2B, lanes 13-16). hPrp 18 was added to anti-hPrp18-depleted extract before the start of the splicing reaction; in this reconstituted extract (Fig. 2, lanes 13-16), the second step of splicing proceeded normally, producing mRNA at levels very similar to those in pre-immune-depleted extract $(<20 \%$ different from lanes $5-8$ in Fig. 2$)$. The first step of splicing was unaffected by the addition of hPrpl8. This result shows that hPrpl 8 was the only essential splicing factor depleted by anti-hPrp18 and establishes that $h \operatorname{Prp} 18$ is required for the second step of pre-mRNA splicing.

The splicing intermediates formed in the absence of hPrp 18 could be converted to products by the addition of $\mathrm{hPrp} 18$. Splicing reactions were carried out for $90 \mathrm{~min}$ in the absence of hPrpl 18 to form spliceosomes containing the lariat intron-exon2 and exon1 intermediates (Fig. 3, lane 1). hPrp18 was added to the reactions, and the amounts of intermediates and products were monitored (Fig. 3, lanes 5-8). Spliced product was formed rapidly on addition of hPrp18 (Fig. 3, lane 5) and accumulated during the 30-min incubation (Fig. 3, lanes 6-8). Quantitation of this gel showed that the intermediates present after $90 \mathrm{~min}$ had been converted to products (Fig. 3B). The decrease in the amounts of intermediates was paralleled by the increase in the amount of product mRNA. Because pre-mRNA levels were essentially constant for the first four time points (up to $16 \mathrm{~min}$ ), the mRNA formed must have come from chasing of the existing intermediates, not from de novo splicing of pre-mRNA. By $30 \mathrm{~min}$, there is a decrease in the amount of premRNA, perhaps because of the recycling of limiting spliceosomal components.

To determine whether hPrpl8 is stably associated with spliceosomes during the splicing reaction, we tried to precipitate pre-mRNA, intermediates, or products from splicing reactions with antibodies against hPrp 18 . We found that very little RNA was immunoprecipitated by anti-hPrp 18 from standard splicing reactions /data not
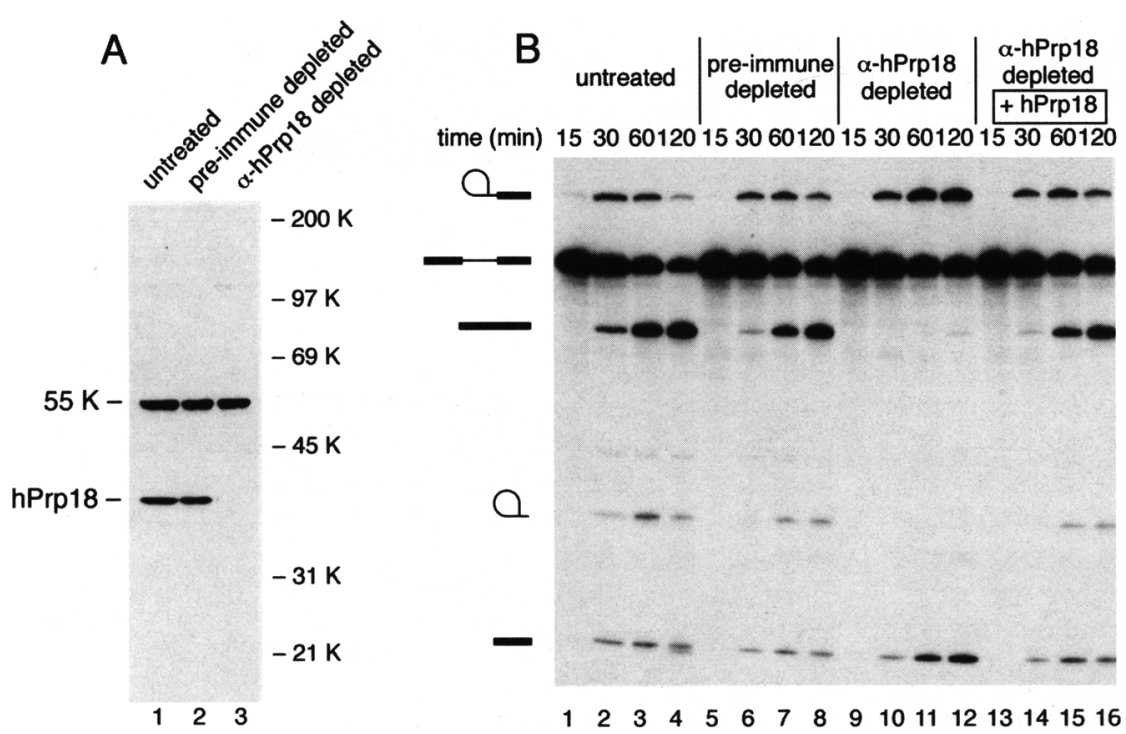

Figure 2. (A) Immunodepletion of hPrp18 from HeLa cell nuclear extracts. A Western blot probed with anti-hPrp18 showing untreated HeLa cell nuclear extract (lane 1), the same extract depleted with antibodies from pre-immune serum (lane 2), or with antibodies against hPrp18 (lane 3). The positions of hPrpl 8 and of a crossreacting $55-\mathrm{kD}$ protein (see text) are indicated. hPrpl 8 was identified by its exact comigration with untagged hPrp18 made in $E$. coli (with $M_{r} \sim 42,000$, near its predicted size of 40,000; data not shown). Four $\mu \mathrm{g}$ of total protein was loaded in each lane. $(B)$ Time course of pre-mRNA splicing in the presence and absence of hPrp18. Splicing of $\beta$-globin pre-mRNA (Krainer et al. 1984) was carried out using the extracts described in $A$ : (Lanes 1-4) Untreated; (lanes 5-8) pre-immune depleted; and (lanes 9-12) hPrp18-immunodepleted HeLa cell nuclear extracts. For lanes 1316, purified recombinant hPrp18 (with a His tag) was added to the hPrp18-depleted extract for the splicing assay. The reactions were allowed to run for the times shown (in $\mathrm{min}$ ) at the top of each lane. The positions of the lariat intron-exon 2 intermediate, pre-mRNA, mRNA, intron, and exon 1 intermediate (listed from top to bottom) are shown. 
Figure 3. (A) Chasing of intermediates to products by addition of hPrp18. $\beta$-Globin pre-mRNA was spliced in a HeLa cell nuclear extract immunodepleted of hPrp18. Splicing was carried out for $90 \mathrm{~min}$ in parallel samples (lanes 1,2,5-8). hPrp 18 protein was added to these reactions and incubation was continued for $4 \mathrm{~min}$ (lane 5), $8 \mathrm{~min}$ (lane 6), $16 \mathrm{~min}$ (lane 7), or $30 \mathrm{~min}$ (lane 8). Lane 2 shows a 30 -min incubation without added hPrpl8, and lanes 3 and 4 show splicing by extract reconstituted with hPrp 18 before the addition of substrate. The positions of the RNAs are indicated as in Fig. 2B. The times shown at the top of each lane are the total reaction times for each sample. $(B)$ Quantitation of the chasing reaction. The amounts of three RNAs, the pre-mRNA (shaded), the lariat intron-exon2 intermediate (hatched), and the mRNA (black), from lanes 1,4-8, and 2 in $A$ were measured. The molar amount of RNA was normalized to the amount of pre-mRNA present at the beginning of the chase. Timeis indicated in min after the addition of hPrpl8.

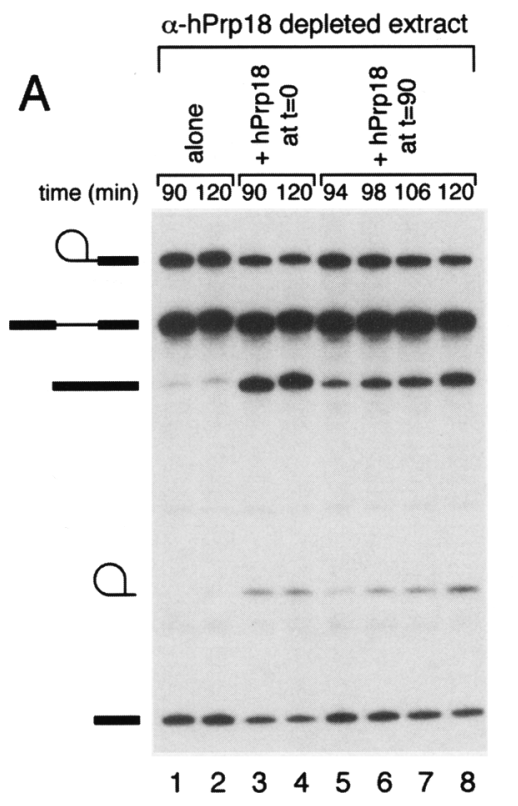

B

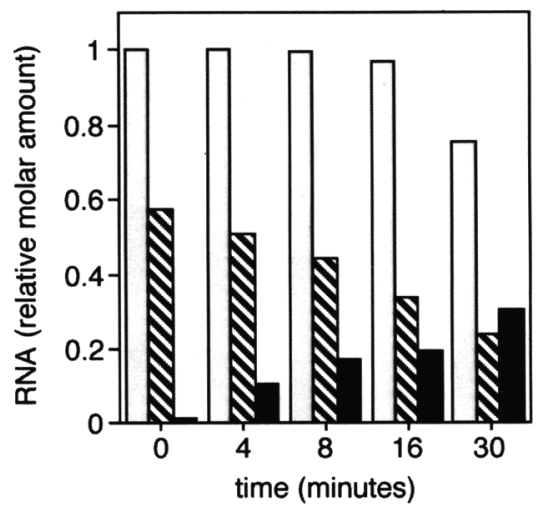

shown). To increase the fraction of spliceosomes available for hPrp 18 binding, splicing reactions were carried out in hPrp18-depleted extracts. Spliceosomes capable of binding hPrpl 8 were then captured by hPrpl 8 immobilized on anti-hPrp18-protein A-Sepharose. With this procedure, substantial fractions $(20 \%-30 \%)$ of both the lariat intron-exon 2 and exon 1 intermediates were bound to the hPrp18-resin (Fig. 4, lanes 3,5), implying that hPrpl 8 is a stable component of the spliceosome before the second transesterification reaction. The precipitation of the RNAs by hPrpl8 did not depend on ATP. Only $-3 \%$ of the pre-mRNA was precipitated (Fig. 4, lanes 3,5$)$, and similar amounts of pre-mRNA were precipitated in control samples (Fig. 4, lanes 7,9).

Significant amounts of the two products, mRNA and intron, were also precipitated (Fig. 4, lanes 3,5). Under the precipitation conditions, the splicing reaction proceeded, and spliced products were formed from the splicing intermediates when hPrpl 8 was present (Fig. 4, lanes $3,5,10)$. This chasing apparently occurred in spliceosomes bound to the resin, as much of the product remained bound, although the possibility that released hPrp 18 effected the chase in solution and then rebound to the column cannot be excluded. In the absence of ATP (Fig. 4, lanes 5,6,10), small amounts of spliced products (both mRNA and intron) were formed, and $~ 30 \%$ of these were bound to the column. In the presence of ATP (Fig. 4 , lanes 3,4 ), more products were formed and $\sim 15 \%$ of these were bound; the amounts of both splicing intermediates declined (to levels similar to those in lane 2 of Fig. 4), but commensurate amounts of products were not seen. Instability of products under the dilute precipitation conditions is the most likely explanation of this observation, because the intermediates were stable in other samples (Fig. 4, lanes 8,10). The control samples showed that precipitation of splicing intermediates or products required both added hPrpl 18 protein (Fig. 4, lanes 7,8) and anti-hPrp18 (Fig. 4, lanes 9,10).

Splicing of several pre-mRNAs was assayed in hPrp18depleted extracts to determine whether hPrp18 is a general splicing factor. In all of the RNAs studied, including the $\beta$-thalassemia IVS1-G1 $\rightarrow$ A (Fig. 5A) (Krainer et al. 1984), ftz (Fig. 5B) (Rio 1988), adenovirus E1A (Fig. 5C) (Schmitt et al. 1987), two $\beta$-tropomyosin RNAs, p7/8/9) (Fig. 5D) and p2p6/8/9)pU (data not shown)(Tsukahara et al. 1994), and adenovirus major late (data not shown) (Michaud and Reed 1993), the second step of splicing was substantially inhibited by depletion of hPrp18 and was restored by addition of hPrp18, showing the involvement of hPrp 18 in the splicing of all of these substrates. Some residual second-step activity was seen in hPrp18-depleted extracts [Figs. 2B (lane 12) and 5]; the amount of activity varied somewhat with different substrates.

The effect of hPrp18 on alternative splicing was tested on pre-mRNAs with duplicated $5^{\prime}$ or $3^{\prime}$ splice sites (Reed and Maniatis 1986; Krainer et al. 1990), as well as the $\beta$-thalassemia, adenovirus, and $\beta$-tropomyosin RNAs mentioned above. Varying the concentration of hPrp18 did not affect splice site selection in any of these substrates. The results on splicing of various transcripts suggest that by itself hPrp18 does not affect alternative splicing.

\section{Functional interchangeability of human and yeast Prp18 proteins}

To assess the functional relationship of $h \operatorname{Prp} 18$ and yeast Prp18, we carried out both in vitro and in vivo comple- 


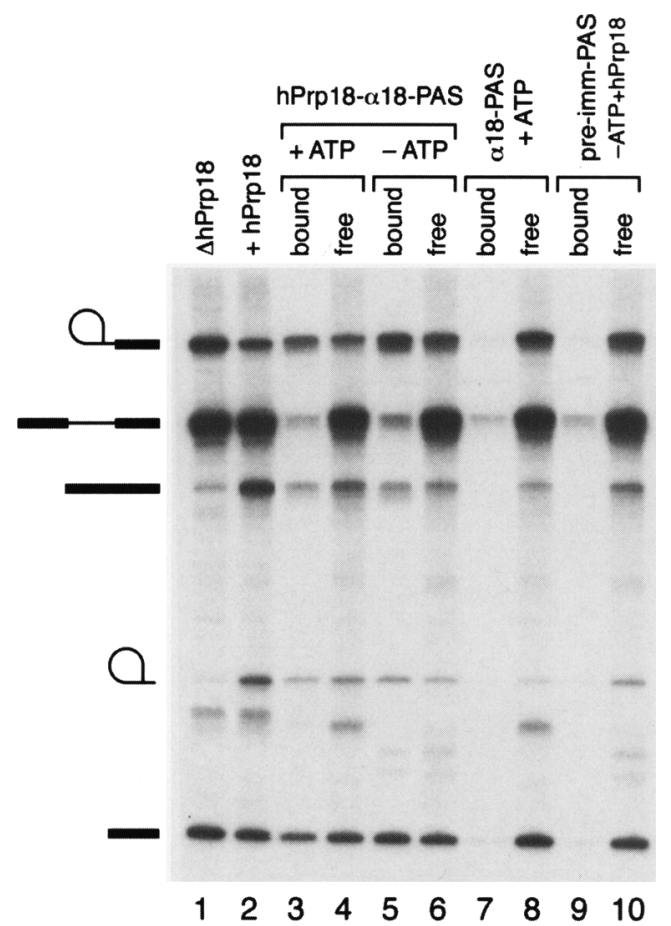

Figure 4. Precipitation of spliceosomes by immobilized hPrp18. $\beta$-Globin pre-mRNA was spliced for $90 \mathrm{~min}$ in a HeLa cell nuclear extract depleted of hPrp18, forming splicing intermediates (lane 1). The intermediates could be chased to products by the addition of hPrp18 (lane 2). Parallel reactions, used for the precipitations, were treated as follows: diluted in splicing buffer, mixed with hPrp18-anti-hPrp18-protein A-Sepharose, and separated into (lane 3 ) a bound fraction and (lane 4) an unbound fraction; diluted in ATP-depleting splicing buffer, mixed with hPrp18-anti-hPrp18-protein A-Sepharose, and separated into (lane 5) a bound fraction and (lane 6) an unbound fraction; diluted in splicing buffer, mixed with anti-hPrp18-protein A-Sepharose (lacking $\mathrm{hPrp} 18$ protein), and separated into (lane 7) a bound fraction and (lane 8) an unbound fraction; diluted in ATP-depleting splicing buffer, mixed with hPrpl 18 protein and pre-immune-antibody-protein A-Sepharose, and separated into (lane 9) a bound fraction and (lane 10) an unbound fraction. Only one-quarter of the samples in lanes 1,2,4,6,8, and 10 was loaded on the gel to facilitate comparisons with the bound fractions. The positions of the RNAs are indicated as in Fig. 2B. The RNAs that migrated between intron and exonl appear to be short lariats, resulting from degradation of lariat intron-exon 2 intermediates. Splicing was less efficient than that shown in other figures because polyvinylalcohol, which nonspecifically increased the background precipitation, was omitted.

mentation experiments. In one in vitro test, yeast Prp18 protein (Horowitz and Abelson 1993b) was added to HeLa cell nuclear extract depleted of hPrpl8 (described above). Yeast Prp18 was able to restore splicing activity to this extract (Fig. 6A, lanes 5,6), although somewhat less efficiently than hPrp18 (Fig. 6A, lanes 3,4). A trivial explanation of the activity of yeast Prp18-that trace amounts of hPrp18 were displaced from residual antihPrpl 8 by the added yeast Prp18-is very unlikely, because anti-hPrp 18 does not cross-react with yeast Prp18 on Western blots and because the levels of hPrp18 and anti-hPrpl 8 in the depleted extract are extremely low (neither protein could be detected; Fig. 2A).

We tried to replace yeast $\operatorname{Prp} 18$ with hPrp 18 in two ways. hPrp 18 was tested for complementation of a yeast extract depleted of Prp18 (Fig. 6B). Depletion of Prp18 blocked the second step of splicing almost completely (Fig. 6B, lanes 1-3), as reported in Horowitz and Abelson (1993a), and full activity was restored on addition of yeast Prp18 (Fig. 6B, lanes 4-6). Addition of hPrp18, in contrast, did not restore the second step of splicing (Fig. $6 \mathrm{~B}$, lanes $7-91$, indicating that hPrp 18 is inactive in yeast splicing in vitro. hPrp18 was also tested for complementing activity in vivo. The hPrp18 protein was expressed from single- or multicopy plasmids in a yeast strain temperature-sensitive for growth because of the disruption of its PRP18 gene (Horowitz and Abelson 1993b). hPrp18 did not rescue the yeast cells at nonpermissive temperatures, whereas yeast Prp18 did (data not shown). Expression of hPrp 18 had no evident effect on yeast growth at permissive temperatures. Both the in vitro and in vivo results show that hPrpl8 cannot substitute for yeast Prp18.

Association of $h \operatorname{Prp} 18$ and the $55-k D$ protein with the snRNPS

Several methods were used to determine whether hPrp 18 is associated with any of the snRNPs. First, snRNPs were fractionated by glycerol gradient sedimentation to resolve the U1, U2, U4/U6, U5, and U4/U6 - U5 snRNPs from one another, as determined by Northern blotting of the snRNAs (Fig. 7A) (Black and Pinto 1989; Behrens and Lührmann 1991). The position of hPrpl8 was determined by Western blotting of gradient fractions (Fig. 7B). hPrpl 8 was found only at the top of the gradient, indicating that the vast majority of hPrp18 was not stably bound to any of the snRNPs. Under all of the tested conditions, we found that hPrp18 remained principally at the top of the gradient and did not comigrate with any of the snRNPs. Second, snRNAs were immunoprecipitated with antitrimethylguanosine under conditions where the snRNPs remain intact (Krainer 1988). No significant amount of hPrp18 was precipitated with the snRNPs (assayed by Western blot; data not shown), consistent with the glycerol gradient results. Finally, no $\mathrm{hPrp} 18$ was found in a preparation of purified U4/ U6 - U5 snRNPs (data not shown; Behrens and Lührmann 1991). All of the results are consistent with the conclusion that hPrp18 is not stably associated with any of the snRNPs.

The experiments on snRNPs showed unexpectedly that the $55-\mathrm{kD}$ protein that cross-reacted with antihPrp18 is part of the U4/U6 snRNP. In glycerol gradient fractionation, the $55-\mathrm{kD}$ protein cosedimented with $\mathrm{U} 4 /$ $\mathrm{U} 6$ and $\mathrm{U} 4 / \mathrm{U} 6 \cdot \mathrm{U} 5$. The $55-\mathrm{kD}$ protein peaked in fractions 17 and 18 at the same place as the U4/U6 - U5 snRNP (Fig. 7). A smaller peak of $55-\mathrm{kD}$ protein was seen in fractions 10-12, comigrating with the similarly small peak of U4/U6 snRNP. Unbound $55-\mathrm{kD}$ protein re- 
Figure 5. Splicing of different premRNAs in hPrp18-depleted extract. Splicing was assayed on four substrates: $(A)$ $\beta$-thalassemia $(\beta$-globin IVS1-G1 $\rightarrow \mathrm{A}) ;(B)$ $f t z$ exons 1 and $2 ;(C)$ adenovirus E1A; and (D) $\beta$-tropomyosin exons 7 and $8 / 9$. Each panel shows the products of three splicing reactions using untreated extract (lane 1); hPrp18-immunodepleted extract (lane 2); and hPrpl8-depleted extract plus hPrpl 8 protein (lane 3). The positions of the various RNAs are shown. The mRNAs resulting from use of cryptic sites 1,2 , and 3 (crl, cr2, and $\mathrm{cr} 3$ ) in the $\beta$-thalassemia premRNA are indicated $(A)$. The cr2 site is dominant and only its intermediates can be identified readily; the band corresponding to the crl lariat intermediate is also indicated. The intermediates and products in splicing of E1A $(C)$ were assigned by comparison with Schmitt et al. (1987). The 13S lariat intermediate and product were reported previously to be multiple bands. Part of the gel has been omitted; the bottom panel in $C$, showing the $13 \mathrm{~S}$ lariat, is from a slightly darker exposure than the top one. The bands marked with an asterisk were noted but not assigned in Schmitt et al. (1987). More activity is seen with untreated extract (lane 1) than with restored extract (lane 3) because of nonspecific reduction in activity caused by the depletion procedure (also seen for $\beta$-globin in Fig. 2).

mained at the top of the gradient. The protein was also efficiently coprecipitated with the snRNPs by antitrimethylguanosine (Krainer 1988) and was present in purified U4/U6 - U5 snRNP (Behrens and Lührmann 1991).
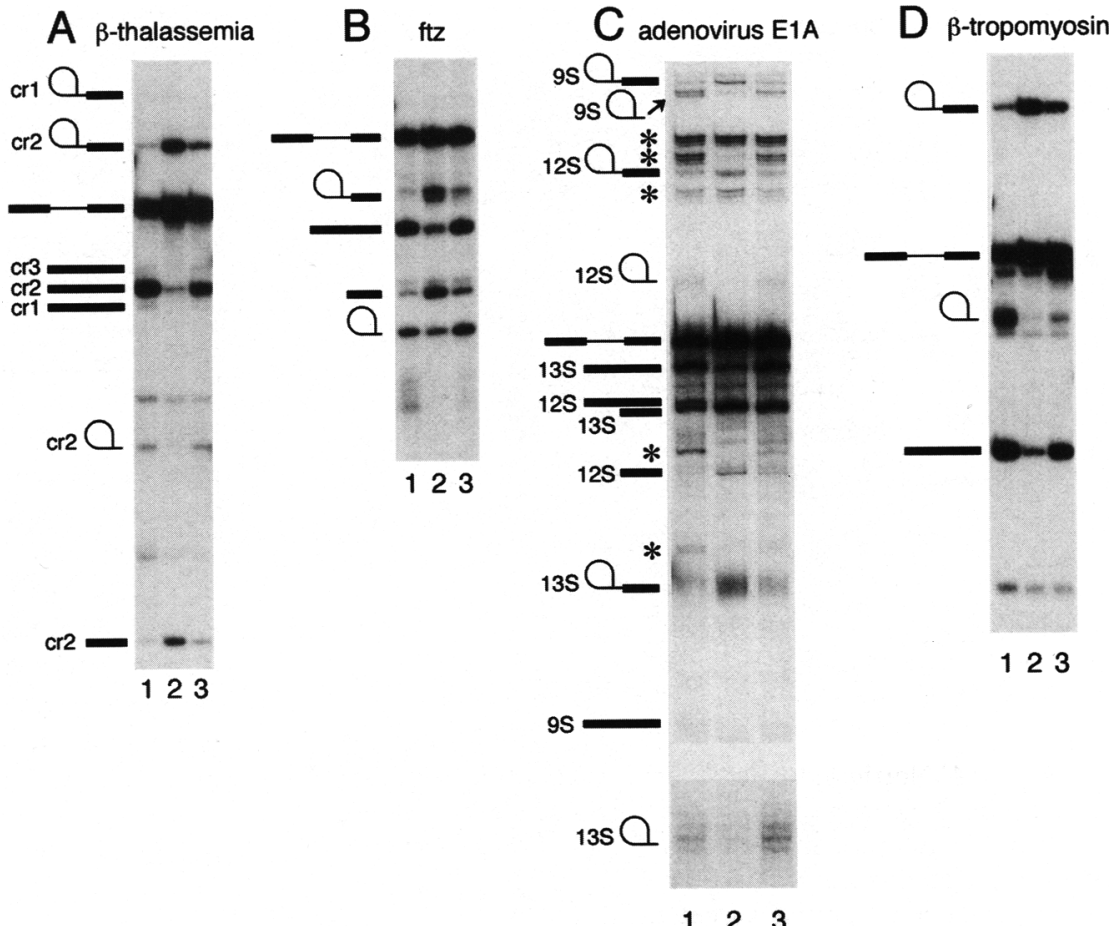

These results show that the $55-\mathrm{kD}$ protein is associated with the U4/U6 snRNP.

Antibodies raised against hPrp18 were used to immunoprecipitate snRNAs from nuclear extract (Fig. 8). Pri-
Figure 6. (A) Reconstitution of human splicing activity with yeast Prp18. Splicing of $\beta$-globin premRNA in HeLa cell nuclear extract depleted of hPrp18 (lanes 1,2), with hPrp18 (lanes 3,4), or with yeast Prp18 (lanes 5,6), carried out for the indicated times. The positions of the RNAs are indicated as in Fig. 2B. In this assay, splicing with yeast Prp 18 produced $\sim 40 \%$ as much mRNA / with a concomitant reduction in lariat intron-exon2 and exonl intermediates) as did splicing with hPrp18. Yeast Prp18 did not affect the first step of the reaction. (B) Attempt to reconstitute yeast splicing activity with hPrp18. Splicing of actin pre-mRNA in a yeast extract immunodepleted of Prp18 (lanes 1-3), with yeast Prp18 (lanes 4-6), or with hPrpl 8 (lanes 7-9), carried out for the indicated times. Splicing in pre-immune-depleted extract is also shown (lanes 10-12). The positions of the RNAs are indicated. Lanes $1-3$ are virtually indistinguishable from lanes $7-9$, suggesting that hPrpl 8 is inactive in yeast splicing. hPrp18 did not affect either step of splicing of actin premRNA in a normal yeast extract (data not shown).
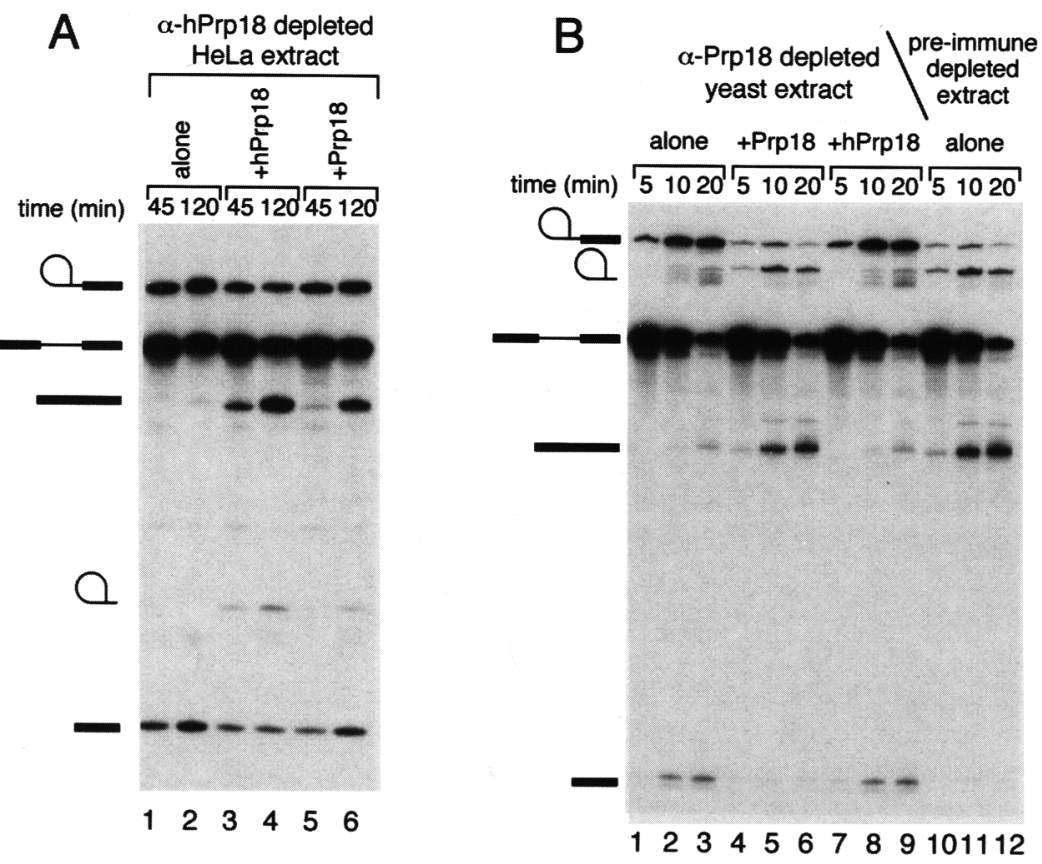


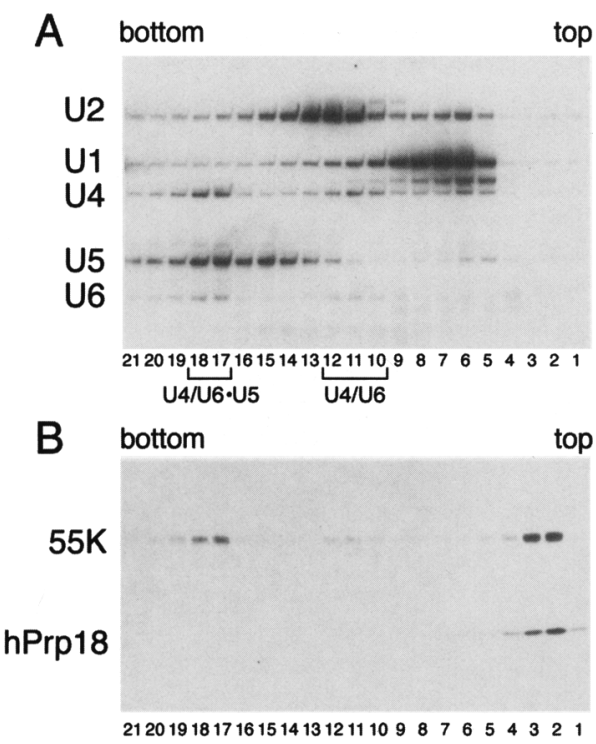

Figure 7. (A) Northern blot of glycerol gradient fractions. HeLa cell nuclear extract was pre-incubated under splicing conditions and then fractionated in a glycerol gradient (Black and Pinto 1989). Fraction numbers are shown along the bottom. The U1, U2, U4, U5, and U6 snRNAs from each fraction were separated on a denaturing polyacrylamide gel and detected by Northern blotting. The U1 snRNP (fractions 6-8) and the U2 snRNP (fractions 12-13) sediment as individual particles. U4 and U6 sediment together as a single particle, giving the small peak in fractions $10-12$ and a larger peak in fractions $17-18$, together with U5 in the U4/U6. U5 snRNP particle. Free U5 snRNP sediments just behind the U4/U6 - U5 snRNP, peaking in fraction 15. The relative sedimentation of the snRNPs is consistent with other reports (Black and Pinto 1989; Behrens and Lührmann 1991). (B) Western blot of glycerol gradient fractions. Glycerol gradient fractions were probed with antibody against hPrp18. Cross-reactivity with the $55-\mathrm{kD}$ protein is discussed in the text. Fraction numbers are shown along the bottom.

marily the U4 and U6 snRNAs were precipitated at moderate salt concentrations $(100-400 \mathrm{~mm})$. The immunoprecipitation of $\mathrm{U} 4$ and $\mathrm{U} 6$ was specific but inefficient: Less than $1 \%$ of the U4 or U6 snRNA present in the extract was precipitated. Precipitation of $U 4$ and U6 was not affected by preincubation of extracts under splicing conditions. The $\mathrm{U} 1$ and $\mathrm{U} 2$ snRNAs were precipitated only at low salt $(50 \mathrm{~mm})$, probably through weak interactions with the U4 and U6 snRNPs. Precipitation of small amounts of U5 snRNA at $100-150 \mathrm{~mm}$ salt is probably attributable to the association of the U5 snRNP with the U4/U6 snRNP (Will and Lührmann 1996). At $600 \mathrm{~mm}$ salt, more U5 was precipitated than at lower salt concentrations. This precipitation was seen at salt concentrations up to $1200 \mathrm{~mm}$ (data not shown) and was abolished by preincubation of extracts under splicing conditions. We believe that the U4 and U6 snRNPs are coimmunoprecipitating with the $55-\mathrm{kD}$ protein, consistent with our other results. The low efficiency of the immunoprecipitation could result from the failure of anti-hPrp18 to recognize the native $55-\mathrm{kD}$ protein effi- ciently (as in the immunodepletions; see Fig. 2A). However, we cannot exclude the possibility that hPrp 18 binds to the U4 or U6 snRNP in amounts too small to be detected in the glycerol gradients and that it mediates the coimmunoprecipitation.

We do not know whether the $55-\mathrm{kD}$ protein is related to hPrp18. All of the polyclonal antibodies raised against hPrp18 (two in rabbits, one in mice) cross-reacted with the $55-\mathrm{kD}$ protein. However, we did not find any direct evidence to suggest that it is related to hPrp 18. Only one mRNA was detected in northern blots using hPrpl8 cDNA as the probe, suggesting that there are no alternatively spliced forms of hPrp18. Two results suggest that the $55-\mathrm{kD}$ protein is not a posttranslationally modified form of hPrp18: first, His-tagged hPrp18, added to HeLa cell extracts under conditions where it is active in splicing, was not modified to any forms with different electrophoretic mobilities; and, second, in vitro translation in rabbit reticulocyte or wheat germ extract gave only the $40-\mathrm{kD}$ product expected for hPrp18. Curiously, antibody against yeast Prp18 reacts with a $54-\mathrm{kD}$ human protein, called $\mathrm{p} 54^{\mathrm{nrb}}$, that is closely related to the splicing factor PSF (Dong et al. 1993). Recombinant p54 ${ }^{\text {nrb }}$ was not recognized by antibody against $h P r p 18$, indicating that the new $55-\mathrm{kD}$ protein is distinct from $\mathrm{p} 54^{\mathrm{nrb}}$.

\section{Discussion}

We have identified and characterized a new human premRNA splicing factor required for the second catalytic step of splicing. The new protein, hPrp18, was found using degenerate PCR based on the sequences of yeast Prp18, a rice EST, and a nematode EST. Homology between hPrpl 18 and yeast Prp 18 is strong only in part of the protein, yet the yeast protein can substitute for the human one in human splicing. In HeLa cell nuclear extracts immunodepleted of hPrp18, the first step of splicing proceeds normally, but the second step is blocked.

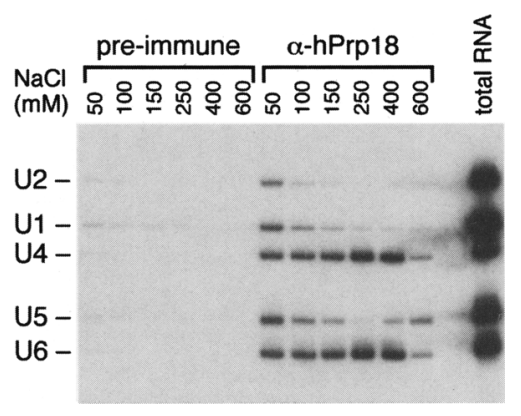

Figure 8. Immunoprecipitation of snRNAs by anti-Prp18. snRNAs were immunoprecipitated from HeLa cell nuclear extract using pre-immune antibodies or antibodies raised against hPrp18. Salt concentrations varying from 50 to $600 \mathrm{~mm}$ were used, as indicated at the top of each lane. A Northern blot of the precipitated snRNAs is shown. The positions of the five snRNAs probed are indicated. In the lane showing total RNA, only one-fifth of the amount of sample used for each of the immunoprecipitations was loaded. 
Addition of purified hPrp18 protein to depleted extracts restores full splicing activity, proving that $h \operatorname{Prp} 18$ is a second-step splicing factor. The splicing intermediates formed in the absence of $h \operatorname{Prp} 18$ can be chased to products by hPrp 18 , showing that the spliceosomes containing these intermediates are functional and suggesting that they are normal intermediates in the splicing pathway.

hPrp 18 is required for the second step of splicing of all of the pre-mRNAs we tested, strongly suggesting that hPrp18 is a general splicing factor. A small amount of product mRNA was observed in the splicing of each of the pre-mRNAs in hPrp18-depleted extracts; different pre-mRNAs gave slightly different amounts of residual second-step activity, but we did not find any pre-mRNA that spliced efficiently in depleted extracts. The residual activity may result from traces of hPrp 18 remaining in the extract, although none was detected by Western blot. Alternatively, the residual activity may be from hPrpl8independent splicing, as was seen in yeast, in which Prp18 is not absolutely required and splicing occurs slowly without it (Horowitz and Abelson 1993a,b).

The first evidence that there are factors specific to the second step of splicing was obtained by biochemical methods (Krainer and Maniatis 1985; Perkins et al. 1986). However, the complete purification of these activities has not been reported. Recently, an activity required for the second step of splicing has been partly characterized (Lindsey et al. 1995). This activity was able to chase spliceosome-bound intermediates to products in the absence of ATP, also a property of $h \operatorname{Prp} 18$ and yeast Prp18 as well as yeast Slu7 (Horowitz and Abelson 1993a; Ansari and Schwer 1995; Jones et al. 1995). Two observations suggest that hPrp18 is distinct from, or is only a part of, this activity. First, yeast $\operatorname{Prp} 18$ could not substitute for the activity (Lindsey et al. 1995) (in contrast to our results for hPrp 18), and second, the activity is found in a large particle (Lindsey et al. 1995), whereas hPrp18, which is found at the top of glycerol gradients, does not appear to be part of a complex.

Recent work has suggested that two proteins are involved in the second step of splicing. A $200-\mathrm{kD}$, U5 snRNP-associated protein has been implicated in the second step of splicing by antibody-inhibition experiments (Lauber et al. 1996). However, the yeast homolog of the U5-200-kD protein is required for the first step of splicing in vivo (Lauber et al. 1996; Noble and Guthrie 1996) and in vitro (Xu et al. 1996). The results for the yeast protein support the idea (Lauber et al. 1996) that the antibody inhibition experiments may have uncovered only part of the function of the human U5-200-kD protein or that the second step may have been inhibited indirectly by steric hindrance of splicing by antibodies within the spliceosome.

The PSF protein has also been implicated in the second step of splicing (Gozani et al. 1996), although high levels of anti-PSF also block the first step (Patton et al. 1993). To date, PSF has only been shown to be required for the splicing of a pre-mRNA derived from the $\alpha$-tropomyosin pre-mRNA; the substrate has an unusual branch point, located far from the $3^{\prime}$ splice site, just upstream of a second pyrimidine tract (Smith and Nadal-Ginard 1989). Because PSF binds preferentially to RNAs with pyrimidine tracts (Patton et al. 1993), it may only be required for splicing of specific RNAs with such tracts. Therefore, hPrp1 8 may be the first general second-step factor found in humans.

Isolation of spliceosomes containing splicing intermediates has allowed the identification of several proteins that join the spliceosome after the initial steps of spliceosome assembly (Gozani et al. 1994). Based on their molecular weights, two of these proteins, a $40-\mathrm{kD}$ U5 snRNP protein (Bach et al. 1989) and SAP45, could be $\mathrm{hPrp} 18$. However, the $40-\mathrm{kD}$ protein is not $\mathrm{hPrp} 18$, as the $40-\mathrm{kD}$ protein is present in the purified $\mathrm{U} 4 / \mathrm{U} 6 \cdot \mathrm{U} 5$ snRNPs that we tested (Behrens and Lührmann 1991) but is not detected by anti-hPrp18; in addition, the electrophoretic mobilities of the $40-\mathrm{kD}$ protein and hPrp 18 are slightly different. We do not know whether $h \operatorname{Prp} 18$ is the same as SAP45.

hPrp 18 binds transiently to the spliceosome during the second step of splicing. From splicing reactions done with hPrp18-depleted extract, splicing intermediates could be efficiently precipitated on immobilized hPrp 18 . Some of the spliceosomes bound to the immobilized hPrp 18 carried out the second step of splicing, forming products that remained bound to the column. In contrast, from normal splicing reactions, only a very small fraction of any splicing RNA could be precipitated with anti-hPrp 18. hPrp18 apparently binds the spliceosome tightly only at the point in the splicing reaction when it is needed. The low yield of immunoprecipitations from standard splicing reactions implies that the association of $h \operatorname{Prp} 18$ with the spliceosome is normally short-lived; even among spliceosomes containing intermediates or products, only a small fraction appear to contain hPrp 18 . The results support a model in which hPrp18 binds to the spliceosome just before the second transesterification reaction, after other stages within the second step. Following the reaction, hPrp18 remains bound to the spliceosome bearing the products, but it is eventually released, perhaps when the spliceosome disassembles.

Two second-step factors in yeast associate transiently with the spliceosome. The Prp16 protein binds to spliceosomes containing intermediates, catalyzes a conformational change in the spliceosome fueled by ATP hydrolysis, and then leaves the spliceosome (Schwer and Guthrie 1991, 1992; Brys and Schwer 1996). Prp16 acts before Prp18 (Horowitz and Abelson 1993a) and does not appear (by immunoprecipitation) to be part of the spliceosome at the time of the second transesterification reaction. The Slu7 protein acts after Prp16, at the same stage of the second step as Prp18 (Ansari and Schwer 1995; Jones et al. 1995). Strong binding of Slu7 to the spliceosome depends on Prp16, and Slu7 remains bound to the spliceosome during the second reaction (Brys and Schwer 1996). Release of Slu7 from the spliceosome occurs only on disassembly of the spliceosome. Our results on spliceosome binding by hPrp18 closely parallel those for Slu7. The behavior of the Prp8 protein is different; it 
appears to be associated stably with the spliceosome throughout the splicing reaction (Whittaker et al. 1990).

One possible site of binding of hPrp18 in the spliceosome is the U5 snRNP. Yeast Prp18 is associated with the U4/U6 - U5 snRNP, primarily through interaction with the U5 snRNP (Horowitz and Abelson 1993b). However, the results for hPrp 18 are different, and we found no evidence of a stable association between hPrp18 and any of the snRNPs. Although the difference in snRNP-binding properties of hPrpl8 and $\operatorname{Prp} 18$ may reflect a fundamental difference in the mechanisms of action of the two proteins, the functional interchangeability of the proteins in human splicing argues that they are mechanistically similar. Prp18 is not bound tightly to U4/U6 - U5, compared with other yeast proteins such as Prp4 and Prp24 (Banroques and Abelson 1989; Petersen-Bjørn et al. 1989; Shannon and Guthrie 1991), and we suspect that in hPrp18 these interactions have been weakened further.

Antibodies raised against hPrpl8, a $40-\mathrm{kD}$ protein, cross-react with a $55-\mathrm{kD}$ protein on Western blots. Although we do not know what the relationship of the $55-\mathrm{kD}$ protein is to $\mathrm{hPrp} 18$, the $55-\mathrm{kD}$ protein does not appear to be either a modified form or an alternatively spliced form of hPrpl 8 . The $55-\mathrm{kD}$ protein is associated with the U4/U6 snRNP. Two other U4/U6-specific proteins are known, one of $60-\mathrm{kD}$ and one of $90-\mathrm{kD}$, but neither has been characterized (Gozani et al. 1994). From their electrophoretic mobilities, it is possible that the $55-\mathrm{kD}$ and $60-\mathrm{kD}$ protein are the same. Three other snRNP proteins of $60 \mathrm{kD}$ have also been reported; they appear to be part of the U4/U6 - U5 snRNP (Behrens and Lührmann 1991; Will and Lührmann 1997). Five proteins associated specifically with U4/U6 are known in yeast (Banroques and Abelson 1989; Petersen-Bjørn et al. 1989; Abovich et al. 1990; Shannon and Guthrie 1991; Cooper et al. 1995).

The interchangeability of hPrp 18 and yeast Prp18 in human splicing was surprising given the relatively weak overall similarity of their sequences (Fig. 1A). During the second step of splicing, hPrpl 8 is likely to interact with several components of the spliceosome. Yeast Prp18 binds to the U4/U6 - U5 snRNP (Horowitz and Abelson $1993 \mathrm{~b}$ ), and genetic experiments suggest that it interacts with the Prp17 and Slu 7 proteins, as well as the U5 snRNA (Frank et al. 1992; Jones et al. 1995), and we expect that hPrp18 would require similar interactions.

We do not know why the complementation results in human and yeast splicing are asymmetric. The replacement of hPrp18 with yeast Prp18 in human splicing implies that they function very similarly and that they share many structural features. The failure of hPrp18 to function in yeast splicing may be attributable to minor functional differences in the proteins or to technical difficulties in the experiments (for example, instability of the protein or improper protein localization). A possible explanation for the failure of hPrp18 to function in yeast is that yeast splicing may require a stronger interaction between Prp18 and the U4/U6 - U5 snRNP. Despite the conservation of at least one portion of hPrp18 in yeast
Prp18, hPrp18 did not function as a dominant negative allele of PRP18 in yeast; such a result might be expected if a conserved part of hPrpl 8 interacted with, and sequestered, another essential splicing factor.

The complementation results imply that important functional domains of hPrp18 are conserved in Prp18. Figure 1A shows that strong homology between the two proteins is restricted to the carboxy-terminal part of the proteins. Within the boxed portion of the sequences, $40 \%$ of the amino acids are identical; however, outside this region the alignment is weak, implying that the carboxy-terminal domain is critical for the functioning of hPrp18. The alignment of the carboxyl termini of hPrp 18 and yeast $\operatorname{Prp} 18$ with the rice and nematode EST sequences (Fig. 1B) shows that this region is highly conserved among all the proteins. Homology is focused in two areas, from amino acids 273-291 and from 303-324, where a consensus sequence can be readily derived. Although a variety of search programs failed to find other proteins related to these in the current data bases, we suggest that this alignment defines a new protein motif. Neither our data nor the data base searches suggest what the function of this evolutionarily conserved region is. It may be involved in interaction with proteins or RNAs, or it may carry out a specific task in the splicing reaction.

Several other homologous splicing proteins in humans and yeast have been identified. These include components of the SF3a and SF3b complexes, which act early in the spliceosome assembly pathway (Behrens et al. 1993; Bennett and Reed 1993; Brosi et al. 1993; Krämer et al. 1995; Gozani et al. 1996; Wells et al. 1996); four snRNP proteins (Smith and Barrell 1991; Liao et al. 1993; Rymond et al. 1993; Polycarpou-Schwarz et al. 1996); and a member of the DEAH protein family (called HRH1) that functions in spliceosome disassembly (Ono et al. 1994). The recently identified human U5-200-kD protein, whose yeast homolog is known as Brr2, Slt22, or Snu246 (Noble and Guthrie 1996; Xu et al. 1996), is both a DEXH protein and a snRNP-associated protein (Lauber et al. 1996). A homolog of Prp8, which is involved in both steps of splicing, has been identified using antibodies (Pinto and Steitz 1989; Garcia-Blanco et al. 1990; Hodges et al. 1995). In these homologs, overall sequence identity (when known) ranges from $25 \%$ to $45 \%$. The human snRNP D1 protein (Rymond et al. 1993), and the HRH1 protein (Ono et al. 1994), two of the most conserved homologs, are functional in vivo in yeast. However, Prp18 is the only yeast splicing factor demonstrated to function in human splicing.

Although pre-mRNA splicing in yeast and mammals follows similar overall pathways, there are some notable differences. The mechanism for recognizing splice sites in mammals, which allows for wide variation in splicesite sequences and for regulated alternative splicing, is more complex than that of yeast, where splice-site sequences are nearly invariant and alternative splice-site selection is absent (Horowitz and Krainer 1994; Black 1995). Identification of 3' splice sites, which occurs during the second step, is likely, therefore, to occur by 
somewhat different mechanisms in mammals and yeast. Previous work on the second step of splicing in mammals has focused on the snRNAs and the pre-mRNA. Experiments on the U2 and U6 snRNAs, which are both required for the second step of splicing, have generally supported the conservation of splicing mechanism between yeast and humans (Fabrizio and Abelson 1990; Shuster and Guthrie 1990; Datta and Weiner 1993; Wolff et al. 1994; Ares and Weiser 1995). In the work reported here, we have characterized a protein required for the second step. The conservation of its function between yeast and humans shows the close phylogenetic conservation of the mechanism of the splicing reaction.

\section{Materials and methods}

\section{Identification and cloning of the hPrp $18 c D N A$}

Alignment of the yeast (L03536), nematode (T01256), and rice (D15798) sequences was the basis for designing two oligonucleotides, 5'-CGGAATTCGC(I/C)AT(I/C)GG(I/C)AATGC (I/C)CC(I/C)TGGC-3' and 5'-CGGGATCCGATGTATTT/G/ T/CI/G/T)ITIGT/T/C)TCGTC-3' (corresponding to amino acids 187-194 and 230-222 of the yeast sequence), that were used for PCR of human CDNA. A fragment of the expected size was generated; its sequence could be aligned with the yeast, rice, and nematode peptide sequences. Two oligonucleotides corresponding to portions of this fragment were used to screen a $\lambda \mathrm{HeLa}$ cDNA library. The resulting clone, containing a 1450-bp insert, was sequenced (accession no. U51990). A Northern blot of poly(A) ${ }^{+}$RNA from HeLa cells gave a single, diffuse band of $\sim 1600$ bases, suggesting that the DNA clone was full-length. The first ATG codon in the hPrpl8 sequence was presumed to be the correct one based on its frame and context (Grünert and Jackson 1994); protein produced in E. coli comigrated exactly with HeLa cell protein detected by Western blots. Several human ESTs that overlap the sequence of hPrp18 have been reported since the completion of this work. The EST sequences are $96 \%-99 \%$ identical to our hPrp 18 sequence. Analysis of the DNA and protein sequences was done using the GCG package (Genetics Computer Group 1994|.

\section{Production of recombinant hPrp18 and antibodies}

The hPrp18 protein with or without an amino-terminal oligohistidine tag was made in $E$. coli using the $\mathrm{T} 7$ expression vectors pET9c and pET19b (Novagen). His-tagged hPrp18, which formed inclusion bodies, was purified to near homogeneity by immobilized metal-ion affinity chromatography in $6 \mathrm{M}$ guanidinium $\cdot \mathrm{HCl}$ (Petty 1993) and then renatured by dialysis against $25 \mathrm{~mm}$ Tris at $\mathrm{pH} 7.5,250 \mathrm{mM} \mathrm{NaCl}, 1 \mathrm{~mm}$ EDTA, $1 \mathrm{~mm}$ DTT, and $10 \%$ glycerol. The purified protein was mostly soluble and was stable for $>1$ year at $4^{\circ} \mathrm{C}$. The His-tagged hPrp 18 was used for raising antibodies and for functional studies.

\section{Immunodepletion of hPrp18}

hPrp18 was immunodepleted from HeLa cell nuclear extracts by incubating extracts with one-fifth volume of protein A-Sepharose-bound antibodies in $20 \mathrm{mM}$ HEPES at $\mathrm{pH} 7.9,750 \mathrm{mM} \mathrm{KCl}$, $10 \%$ glycerol, $1 \mathrm{~mm}$ DTT, $0.2 \mathrm{~mm}$ EDTA, $0.1 \mathrm{~mm}$ PMSF for $1 \mathrm{hr}$ at $4^{\circ} \mathrm{C}$ twice, followed by incubation with one-tenth volume protein A-Sepharose in the same buffer for $30 \mathrm{~min}$ to remove any released antibody. The depleted extract was dialyzed against the same buffer with $100 \mathrm{~mm} \mathrm{KCl}$. Immunoprecipita- tions from ${ }^{35}$ S-labeled nuclear extract showed that hPrp18 was the predominant precipitated protein. The $55-\mathrm{kD}$ protein could not be detected in Western blots of the proteins immunoprecipitated under hPrp18-depletion conditions.

\section{Splicing assays}

Splicing in HeLa-cell nuclear extracts was carried out as described previously (Krainer et al. 1984). For reconstitution of splicing activity, 10-50 ng purified recombinant hPrp18 was added per microliter of nuclear extract $(7 \mu \mathrm{g}$ protein). From Western blots we estimated that the concentration of hPrp18 in our HeLa nuclear extracts was $5 \mathrm{ng} / \mu \mathrm{l}$; we obtained essentially full restoration of splicing with $2 \mathrm{ng}$ of recombinant hPrp18 per microliter extract. For reconstitution of activity with yeast Prp18, 100 ng Prp18 was added per microliter HeLa nuclear extract. Splicing substrates were transcribed from pSP64-H $\beta \Delta 6$

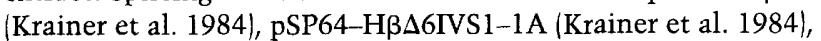
pSP64-HB5'D16X (Reed and Maniatis 1986; Krainer et al. 1990), pSP64-HB3'D115 (Reed and Maniatis 1986; Krainer et al. 1990), p7(8/9) (Tsukahara et al. 1994), p2p6/8/9/pU (Tsukahara et al. 1994), pSP65-SP4 (Schmitt et al. 1987), SP6-ftz (Rio 1988), and pAdML (Michaud and Reed 1993).

Yeast splicing, immunodepletion of Prp18 from yeast extracts, and purification of Prp18 protein were carried out as described previously (Lin et al. 1985; Horowitz and Abelson 1993a). Forty nanograms hPrp18 (40 ng) was added per microliter of yeast extract in our attempt to restore activity to the Prp18-depleted extract.

\section{Immunoprecipitation of spliceosomes}

Antiserum against hPrpl8 (or pre-immune serum) was incubated with protein A-Sepharose $(3 \mu \mathrm{l}$ serum per microliter resin). After extensive washing, the resin was incubated with hPrp18 (50 ng per microliter resin) and washed again, yielding hPrp18-anti-hPrp18-protein A-Sepharose. Splicing reactions were carried out in hPrp18-depleted extracts for 90 min under normal splicing conditions except that polyvinylalcohol was omitted, diluted 10-fold either in splicing buffer or in ATPdepleting splicing buffer (including glucose and hexokinase, but lacking creatine phosphate and ATP; brief incubation in this buffer reduced the concentration of ATP to $\sim 0.3 \mu \mathrm{M}$ ), and mixed with the hPrp18-anti-hPrp18-protein A-Sepharose $11 \mu \mathrm{l}$ reaction per microliter resin) for $45 \mathrm{~min}$ at $30^{\circ} \mathrm{C}$. The mixture was spun in a microcentrifuge filter, separating the resin from the unbound material; the resin was washed once briefly, and the wash was removed by filtration and combined with the unbound fraction. Bound RNA was eluted from the resin with proteinase $\mathrm{K}$ and SDS.

\section{Expression of hPrp18 in yeast}

The hPrp18 gene was placed under control of the GAL1 promoter using the plasmids pSEYC68GAL (single copy) and pSEY18GAL (multicopy) (Herman and Emr 1990). hPrp18 did not rescue the temperature-sensitive defect of the yeast PRP18knockout strain DH120R (Horowitz and Abelson 1993b) at $33^{\circ} \mathrm{C}$ or $37^{\circ} \mathrm{C}$ under a variety of induction conditions. At $23^{\circ} \mathrm{C}$ (a permissive temperature) expression of hPrp18 had no apparent effect on yeast growth. Expression of hPrpl 8 in yeast was verified by Western blot. Yeast Prp18 expressed from analogous plasmids always rescued the yeast. 


\section{Glycerol gradients}

Glycerol gradients were run according to described procedures (Black and Pinto 1989; Behrens and Lührmann 1991), both with and without preincubation under splicing conditions. RNAs were detected on Northern blots with RNA probes (Konarska and Sharp 1987). hPrp18 and the 55-kD protein were detected by Western blotting using enhanced chemiluminescence.

\section{Immunoprecipitations of SnRNPS}

Immunoprecipitations using antibodies against trimethylguanosine or hPrp18 were carried out according to procedures described previously (Krainer 1988; Banroques and Abelson 1989; Horowitz and Abelson 1993b).

\section{Acknowledgments}

We thank M. Konarska, A.R. Kerlavage, A. Mayeda, R. Reed, and D. Helfman for plasmid DNAs; C. Will and R. Lührmann for purified snRNPs; M. Meyer for ${ }^{35}$ S-labeled extract; J. Cáceres, G. Screaton, M. Strathmann, D. DeWald, R. Pruzan, and K. Collins for helpful discussions; and M. Selvakumar, M. Murray, J. Cáceres, and C. Autexier for comments on the manuscript. This work was supported by National Institutes of Health grant GM42699 and by a scholarship from the Pew Charitable Trusts to A.R.K.

The publication costs of this article were defrayed in part by payment of page charges. This article must therefore be hereby marked "advertisement" in accordance with 18 USC section 1734 solely to indicate this fact.

\section{References}

Abovich, N., P. Legrain, and M. Rosbash. 1990. The yeast PRP6 gene encodes a U4/U6 small nuclear ribonucleoprotein particle (snRNP) protein, and the PRP9 gene encodes a protein required for U2 snRNP binding. Mol. Cell. Biol. 10: 64176425.

Adams, M.D., D.Z. Rudner, and D.C. Rio. 1996. Biochemistry and regulation of pre-messenger-RNA splicing. Curr. Opin. Cell Biol. 8: 331-339.

Ansari, A. and B. Schwer. 1995. SLU7 and a novel activity, SSF1, act during the PRP16-dependent step of yeast pre-mRNA splicing. EMBO I. 14: 4001-4009.

Ares, M., Jr. and B. Weiser. 1995. Rearrangement of snRNA structure during assembly and function of the spliceosome. Prog. Nucleic Acid Res. Mol. Biol. 50: 131-159.

Bach, M., G. Winkelmann, and R. Lührmann. 1989. 20S small nuclear ribonucleoprotein U5 shows a surprisingly complex protein composition. Proc. Natl. Acad. Sci. 86: 6038-6042.

Banroques, J. and J.N. Abelson. 1989. PRP4: A protein of the yeast U4/U6 small nuclear ribonucleoprotein particle. Mol. Cell. Biol. 9: 3710-3719.

Behrens, S.-E. and R. Lührmann. 1991. Immunoaffinity purification of a [U4/U6.U5] tri-snRNP for human cells. Genes \& Dev. 5: 1439-1452.

Behrens, S.-E., F. Galisson, P. Legrain, and R. Lührmann. 1993. Evidence that the $60-\mathrm{kDa}$ protein of $17 \mathrm{~S}$ U2 small nuclear ribonucleoprotein is immunologically and functionally related to the yeast PRP9 splicing factor and is required for the efficient formation of prespliceosomes. Proc. Natl. Acad. Sci. 90: 8229-8233.

Bennett, M. and R. Reed. 1993. Correspondence between a mammalian spliceosome component and an essential yeast splicing factor. Science 262: 105-108.
Black, D.L. 1995. Finding splice sites within a wilderness of RNA. RNA 1: 763-771.

Black, D.L. and A.L. Pinto. 1989. U5 small nuclear ribonucleoprotein: RNA structure analysis and ATP-dependent interaction with U4/U6. Mol. Cell. Biol. 9: 3350-3359.

Brosi, R., K. Gröning, S.-E. Behrens, R. Lührmann, and A. Krämer. 1993. Interaction of mammalian splicing factor SF3a with U2 snRNP and relation of its $60-\mathrm{kD}$ subunit to yeast PRP9. Science 262: 102-105.

Brys, A. and B. Schwer. 1996. Requirement for SLU7 in yeast pre-mRNA splicing is dictated by the distance between the branchpoint and the 3' splice site. RNA 2: 707-717.

Cooper, M., L.H. Johnston, and J.D. Beggs. 1995. Identification and characterization of Usslp (Sdb23p): A novel U6 snRNAassociated protein with significant similarity to core proteins of small nuclear ribonucleoproteins. EMBO $J$. 14: 2066-2075.

Couto, J.R., J. Tamm, R. Parker, and C. Guthrie. 1987. A transacting suppressor restores splicing of a yeast intron with a branch point mutation. Genes \& Dev. 1: 445-455.

Datta, B. and A.M. Weiner. 1993. The phylogenetically invariant ACAGAGA and AGC sequences of U6 small nuclear RNA are more tolerant of mutation in human cells than in Saccharomyces cerevisiae. Mol. Cell. Biol. 13: 5377-5382.

Dong, B., D.S. Horowitz, R. Kobayashi, and A.R. Krainer. 1993. Purification and cDNA cloning of HeLa cell p54 $4^{\text {nrb }}$, a nuclear protein with two RNA recognition motifs and extensive homology to human splicing factor PSF and Drosophila NONA/BJ6. Nucleic Acids Res. 21: 4085-4092.

Fabrizio, P. and J. Abelson. 1990. Two domains of yeast U6 small nuclear RNA required for both steps of nuclear precursor messenger RNA splicing. Science 250: 404-409.

Frank, D. and C. Guthrie. 1992. An essential splicing factor, SLU7, mediates $3^{\prime}$ splice site choice in yeast. Genes \& Dev. 6: 2112-2124.

Frank, D., B. Patterson, and C. Guthrie. 1992. Synthetic lethal mutations identify interactions between U5 snRNA and four proteins required for the second step of splicing. Mol. Cell. Biol. 12: 5197-5205.

Garcia-Blanco, M.A., G.J. Anderson, J. Beggs, and P.A. Sharp. 1990. A mammalian protein of $220 \mathrm{kDa}$ binds pre-messenger-RNAs in the spliceosome-A potential homolog of the yeast PRP8 protein. Proc. Nat1. Acad. Sci. 87: 30823086.

Genetics Computer Group. 1994. Program Manual for the Wisconsin Package, Version 8. Genetics Computer Group, Madison, WI.

Gozani, O., J.G. Patton, and R. Reed. 1994. A novel set of spliceosome-associated proteins and the essential splicing factor PSF bind stably to pre-mRNA prior to catalytic step II of the splicing reaction. EMBO J. 13: $3356-3367$.

Gozani, O., R. Feld, and R. Reed. 1996. Evidence that sequenceindependent binding of highly conserved $U 2$ snRNP proteins upstream of the branch site is required for assembly of spliceosomal complex A. Genes \& Dev. 10: 233-243.

Grünert, S. and R.J. Jackson. 1994. The immediate downstream codon strongly influences the efficiency of utilization of eukaryotic translation intiation codons. EMBO J. 13: 36183630 .

Herman, P.K. and S.D. Emr. 1990. Characterization of VPS34, a gene required for vacuolar protein sorting and vacuole segregation in Saccharomyces cerevisiae. Mol. Cell. Biol. 10: $6742-6754$.

Hodges, P.E., S.P. Jackson, J.D. Brown, and J.D. Beggs. 1995. Extraordinary sequence conservation of the PRP8 splicing factor. Yeast 11: 337-342. 
Horowitz, D.S. and J. Abelson. 1993a. Stages in the second reaction of pre-mRNA splicing: The final step is ATP independent. Genes \& Dev. 7: 320-329.

__ 1993b. A U5 small nuclear ribonucleoprotein particle protein involved only in the second step of splicing in Saccharomyces cerevisiae. Mol. Cell. Biol. 13: 2959-2970.

Horowitz, D.S. and A.R. Krainer. 1994. Mechanisms for selecting $5^{\prime}$ splice sites in mammalian pre-mRNA splicing. Trends Genet. 10: 100-106.

Jones, M.H., D.N. Frank, and C. Guthrie. 1995. Characterization and functional ordering of Slu $7 p$ and Prpl $7 p$ during the second step of pre-mRNA splicing in yeast. Proc. Natl. Acad. Sci. 92: 9687-9691.

Konarska, M.M. and P.A. Sharp. 1987. Interactions between small nuclear ribonucleoprotein particles in formation of spliceosomes. Cell 49: 763-774.

Krainer, A.R. 1988. Pre-mRNA splicing by complementation with purified human U1, U2, U4/U6 and U5 snRNPs. Nucleic Acids Res. 16: 9415-9429.

Krainer, A.R. and T. Maniatis. 1985. Multiple factors including the small ribonucleoproteins $\mathrm{U} 1$ and $\mathrm{U} 2$ are necessary for pre-mRNA splicing in vitro. Cell 42: 725-736.

Krainer, A.R., T. Maniatis, B. Ruskin, and M.R. Green. 1984. Normal and mutant human $\beta$-globin pre-mRNAs are faithfully and efficiently spliced in vitro. Cell 36: 993-1005.

Krainer, A.R., G.C. Conway, and D. Kozak. 1990. The essential pre-mRNA splicing factor SF2 influences 5 ' splice site selection by activating proximal sites. Cell 62: 35-42.

Krämer, A. 1996. The structure and function of proteins involved in mammalian pre-mRNA splicing. Annu. Rev. Biochem. 65: 367-409.

Krämer, A., F. Mulhauser, C. Wersig, K. Gröning, and G. Bilbe. 1995. Mammalian splicing factor SF3a120 represents a new member of the SURP family of proteins and is homologous to the essential splicing factor PRP21p of Saccharomyces cerevisiae. RNA 1: 260-272.

Lauber, J., P. Fabrizio, S. Teigelkamp, W.S. Lane, E. Hartmann, and R. Lührmann. 1996. The HeLa $200 \mathrm{kDa}$ U5 snRNP. specific protein and its homologue in Saccharomyces cerevisiae are members of the DEXH-box protein family of putative RNA helicases. EMBO J. 15: 4001-4015.

Liao, X.C., J. Tang, and M. Rosbash. 1993. An enhancer screen identifies a gene that encodes the yeast U1 snRNP A protein: Implications for snRNP protein function in pre-mRNA splicing. Genes \& Dev. 7: 419-428.

Lin, R.-J., A.J. Newman, S.-C. Cheng, and J. Abelson. 1985. Yeast mRNA splicing in vitro. $J$. Biol. Chem. 260: 1478014792.

Lindsey, L.A., A.J. Crow, and M.A. Garcia-Blanco. 1995. A mammalian activity required for the second step of pre-messenger RNA splicing. J. Biol. Chem. 270: 13415-13421.

Lustig, A.J., R.-J. Lin, and J. Abelson. 1986. The yeast RNA gene products are essential for mRNA splicing in vitro. Cell 47: 953-963.

Madhani, H. and C. Guthrie. 1992. A novel base-pairing interaction between $\mathrm{U} 2$ and $\mathrm{U} 6$ snRNAs suggests a mechanism for the catalytic activation of the spliceosome. Cell 71: 803-817.

McPheeters, D.S. and J. Abelson. 1992. Mutational analysis of the yeast U2 snRNA suggests a structural similarity to the catalytic core of group I introns. Cell 71: 819-831.

Michaud, S. and R. Reed. 1993. A functional association between the $5^{\prime}$ and $3^{\prime}$ splice sites is established in the earliest prespliceosome complex $(E)$ in mammals. Genes \& DeV. 7: 1008-1020.

Newman, A.J. and C. Norman. 1992. U5 snRNA interacts with exon sequences at $5^{\prime}$ and $3^{\prime}$ splice sites. Cell 68: 743-754.
Noble, S.M. and C. Guthrie. 1996. Identification of novel genes required for yeast pre-mRNA splicing by means of coldsensitive mutations. Genetics 143: 67-80.

Ono, Y., M. Ohno, and Y. Shimura. 1994. Identification of a putative RNA helicase (HRH1), a human homolog of yeast Prp22. Mol. Cell. Biol. 14: 7611-7620.

Patton, J.G., E.B. Porro, J. Galceran, P. Tempst, and B. NadalGinard. 1993. Cloning and characterization of PSF, a novel pre-mRNA splicing factor. Genes \& Dev. 7: 393-406.

Perkins, K.K., H.M. Furneaux, and J. Hurwitz. 1986. RNA splicing products formed with isolated fractions from HeLa cells are associated with fast-sedimenting complexes. Proc. Natl. Acad. Sci. 83: 887-891.

Petersen-Bjørn, S., A. Soltyk, J.D. Beggs, and J.D. Friesen. 1989. PRP4 (RNA4) from Saccharomyces cerevisiae: Its gene product is associated with the U4/U6 small nuclear ribonucleoprotein particle. Mol. Cell. Biol. 9: 3698-3709.

Petty, K.J. 1993. Metal-chelate affinity chromatography. In Current protocols in molecular biology, John Wiley \& Sons, New York, NY.

Pinto, A.L. and J.A. Steitz. 1989. The mammalian analogue of the yeast PRP8 splicing protein is present in the U4/5/6 small ribonucleoprotein particle and the spliceosome. Proc. Natl. Acad. Sci. 86: 8742-8746.

Polycarpou-Schwarz, M., S.I. Gunderson, S. Kandels-Lewis, B. Séraphin, and I.W. Mattaj. 1996. Drosophila SNF/D25 combines the functions of the two snRNP proteins U1A and $\mathrm{U}^{2} \mathrm{~B}^{\prime \prime}$ that are encoded separately in human, potato, and yeast. RNA 2: 11-23.

Reed, R. and T. Maniatis. 1986. A role for exon sequences and splice-site proximity in splice-site selection. Cell 46: 681690.

Rio, D.C. 1988. Accurate and efficient pre-mRNA splicing in Drosophila cell-free extracts. Proc. Natl. Acad. Sci. 85: 2904-2908.

Rymond, B.C., L.A. Rokeach, and S.A. Hoch. 1993. Human snRNP polypeptide D1 promotes pre-mRNA splicing in yeast and defines nonessential yeast $S$ mdlp sequences. Nucleic Acids Res. 21: 3501-3505.

Schmitt, P., R. Gattoni, P. Keohavong, and J. Stévenin. 1987. Alternative splicing of E1A transcripts of adenovirus requires appropriate ionic conditions in vitro. Cell 50: 31-39.

Schwer, B. and C. Guthrie. 1991. PRP16 is an RNA-dependent ATPase that interacts transiently with the spliceosome. $\mathrm{Na}$ ture 349: 494-499.

-1992. A conformational rearrangement in the spliceosome is dependent on PRP16 and ATP hydrolysis. EMBO \%. 11: 5033-5039.

Shannon, K.W. and C. Guthrie. 1991. Suppressors of a U4 snRNA mutation define a novel U6 snRNP protein with RNA-binding motifs. Genes \& Dev. 5: 773-785.

Shuster, E.O. and C. Guthrie. 1990. Human U2 can function in pre-mRNA splicing in yeast. Nature 345: 270-273.

Smith, C.W.J. and B. Nadal-Ginard. 1989. Mutually exclusive splicing of $\alpha$-tropomyosin exons enforced by an unusual lariat branch point location: Implications for constitutive splicing. Cell 56: 749-758.

Smith, V. and B.G. Barrell. 1991. Cloning of a yeast U1 snRNP $70 \mathrm{~K}$ protein homologue: Functional conservation of an RNA-binding domain between humans and yeast. $E M B O I$. 10: $2627-2634$.

Teigelkamp, S., E. Whittaker, and J.D. Beggs. 1995. Interaction of the yeast splicing factor PRP8 with substrate RNA during both steps of splicing. Nucleic Acids Res. 23: 320-326.

Tsukahara, T., C. Casciato, and D.M. Helfman. 1994. Alternative splicing of $\beta$-tropomyosin pre-mRNA: Multiple cis-ele- 
ments can contribute to the use of the $5^{\prime}$ - and $3^{\prime}$-splice sites of the nonmuscle/smooth muscle exon 6. Nucleic Acids Res. 22: 2318-2325.

Umen, J.G. and C. Guthrie. 1995a. A novel role for a U5 snRNP protein in 3' splice site selection. Genes \& Dev. 9: 855-868. . 1995b. Prp16p, Slu7p, and Prp8p interact with the $3^{\prime}$ splice site in two distinct stages during the second catalytic step of pre-mRNA splicing. RNA 1: 584-597.

. 1995c. The second catalytic step of pre-mRNA splicing. RNA 1: 869-885.

Vijayraghavan, U. and J. Abelson. 1990. PRP18, a protein required for the second reaction in pre-mRNA splicing. Mol. Cell. Biol. 10: 324-332.

Vijayraghavan, U., M. Company, and J. Abelson. 1989. Isolation and characterization of pre-mRNA splicing mutants of Saccharomyces cerevisiae. Genes \& Dev. 3: 1206-1216.

Wells, S.E., M. Neville, M. Haynes, J. Wang, H. Igel, and M. Ares, Jr. 1996. CUS1, a suppressor of cold-sensitive U2 snRNA mutations, is a novel yeast splicing factor homologous to human SAP 145. Genes \& Dev. 10: 220-232.

Whittaker, E., M. Lossky, and J.D. Beggs. 1990. Affinity purification of spliceosomes reveals that the precursor RNA processing protein PRP8, a protein in the U5 small nuclear ribonucleoprotein particle, is a component of yeast spliceosomes. Proc. Nat1. Acad. Sci. 87: 2216-2219.

Will, C.L. and R. Lührmann. 1997. snRNP structure and function. In Eukaryotic mRNA processing (ed. A. R. Krainer), IRL Press, Oxford. (In press.)

Wolff, T., R. Menssen, J. Hammel, and A. Bindereif. 1994. Splicing function of mammalian U6 small nuclear RNA: Conserved positions in central domain and helix I are essential during the first and second step of pre-mRNA splicing. Proc. Nat1. Acad. Sci. 91: 903-907.

Xu, D., S. Nouraini, D. Field, S.J. Tang, and J.D. Friesen. 1996. An RNA-dependent ATPase associated with U2/U6 snRNAs in pre-mRNA splicing. Nature 381: 709-713. 


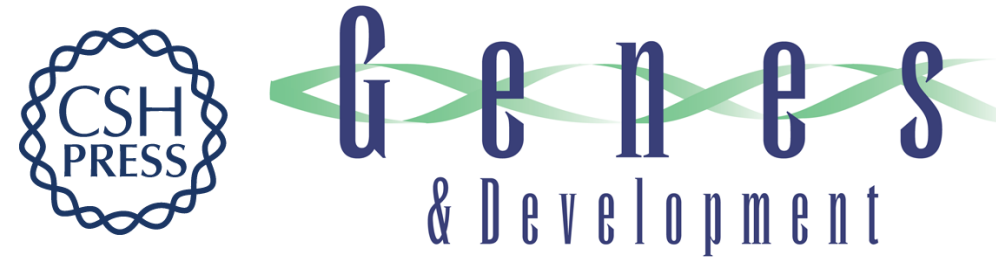

\section{A human protein required for the second step of pre-mRNA splicing is functionally related to a yeast splicing factor.}

D S Horowitz and A R Krainer

Genes Dev. 1997, 11:

Access the most recent version at doi:10.1101/gad.11.1.139

References This article cites 74 articles, 41 of which can be accessed free at:

http://genesdev.cshlp.org/content/11/1/139.full.html\#ref-list-1

License

Email Alerting

Service

Receive free email alerts when new articles cite this article - sign up in the box at the top right corner of the article or click here.

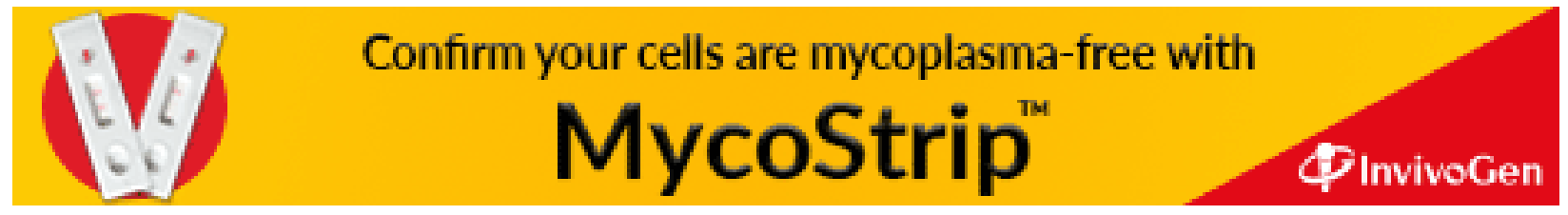

